\title{
Assessment of allelopathic potential of the salicylic acid on target plants: Euphorbia
}

\section{heterophylla and Bidens pilosa}

Avaliação do potencial allelopático do ácido salicílico em plantas alvo: Euphorbia heterophylla e

Bidens pilosa

Evaluación del potencial alelopático del ácido salicílico en plantas objetivo: Euphorbia heterophylla

y Bidens pilosa

Received: 12/17/2021 | Reviewed: 12/23/2021 | Accept: 12/29/2021| Published: 01/02/2022

Gabrielli Monzani de Lima

ORCID: https://orcid.org/0000-0002-9767-6191

Federal University of Technology, Brazil

E-mail: gabym.lima@hotmail.com

José Donizetti de Lima

ORCID: https://orcid.org/0000-0001-5260-9035

Federal University of Technology, Brazil

E-mail: donizetti@utfpr.edu.br

Vanderlei Aparecido de Lima

ORCID: https://orcid.org/0000-0003-1569-8723

Federal University of Technology, Brazil E-mail: valima@utfpr.edu.br

Michelangelo Muzell Trezzi

ORCID: https://orcid.org/0000-0003-3100-0639

Federal University of Technology, Brazil E-mail: trezzim@gmail.com

Beatriz Helena Lameiro de Noronha Sales Maia ORCID: https://orcid.org/0000-0001-5896-2892

Federal University of Paraná, Brazil

E-mail: bhsalesmaia@gmail.com

Ana Paula Palaro Klein Hendges

ORCID: https://orcid.org/0000-0001-5962-6399

Federal University of Paraná, Brazil

E-mail: anah_klein@hotmail.com

Martha Menin

ORCID: https://orcid.org/0000-0002-4699-8334

Federal University of Technology, Brazil

E-mail: martha_menin@hotmail.com

Sirlei Dias Teixeira

ORCID: https://orcid.org/0000-0003-1135-6785

Federal University of Technology, Brazil

E-mail: sirlei@utfpr.edu.br

\begin{abstract}
Salicylic acid has one of its characteristics the allelopathic potential. The present paper, is a research quantitative in nature aimed to assess the allelopathic potential of salicylic acid to identify the best concentration range for other pure substances. The bioassays were performed in a BOD incubator, seeking to assess the seedling growth by measuring the radicle and hypocotyl length. Each bioassay occurred for 12 days. The concentrations of salicylic acid used in the bioassays were: $1000,750,500,250,125$, and $62.5 \mathrm{ppm}$ and control. The obtained data were submitted to the tests: Kolmogorov-Smirnov normality, the two-way ANOVA with repetition, and Tukey. Based on the results obtained, it was possible to observe that several concentrations demonstrated significant differences, i.e., there is an allelopathic activity in both species (Euphorbia heterophylla and Bidens pilosa). The highlights were for the concentrations of 750 and $1000 \mathrm{ppm}$ for E. heterophylla and 500, 750 and $1000 \mathrm{ppm}$ for B. pilosa. However, there was no significant difference between these concentration groups. The radicle's length was the part most negatively affected. These results can be used to identify better concentrations for other pure substances, which are usually obtained in small quantities, being useful in the formulation of a product with characteristics of bio-herbicides.
\end{abstract}

Keywords: Allelochemicals; Bio-herbicide; Phytotoxicit; Seedling growth. 


\section{Resumo}

O ácido salicílico tem como uma de suas características, o potencial alelopático, além de ser um produto sintetizável, podendo substituir outras substâncias, que possuem a mesma característica, porém de difícil obtenção. Utilizado para o estudo de potencial alelopático em teste preliminar para determinação de faixa de concentração (pesquisa de natureza quantitativa), de substâncias puras, que influenciem negativamente em plantas alvos selecionadas. Os bioensaios foram realizados em incubadora BOD. Sendo avaliado o crescimento das plântulas, medindo-se o comprimento da radícula e do hipocótilo. As sementes utilizadas como plantas alvos, foram a leiteira (Euphorbia heterophylla) e o picão-preto (Bidens pilosa). Cada bioensaio ocorreu por 12 dias, sendo que as medidas da radícula, bem como do hipocótilo foram realizadas de 3 em 3 dias para as concentrações de ácido salicílico: 1000, 750, 500, 250, 125 e 62,5 ppm e controle (água destilada). Os dados foram submetidos, inicialmente ao teste de normalidade de Kolmogorov-Smirnov e posteriormente aos testes de ANOVA de dois fatores com repetição e Tukey. Baseado nos resultados obtidos foi possível observar que diversas concentrações apresentaram diferenças significativas, ou seja, houve atividade alelopática, ocasionando diferença entre os comprimentos tanto de radícula como de hipocótilo. Houve uma brusca redução no crescimento de ambas as espécies. Os destaques foram para as concentrações de 750 e 1000 ppm para E. heterophylla e 500, 750 e 1000 ppm para B. pilosa. Porém, entre esses grupos não apresentaram diferença significativa. O comprimento da radícula foi a parte mais afetada negativamente, pois é onde ocorre a absorção dos nutrientes. Com esses resultados, é possível determinar a melhor faixa de concentração e posteriormente aplicar aos bioensaios com outras substâncias puras, viabilizando a formulação de um produto com características de bio-herbicida.

Palavras-chave: Aleloquímicos; Fitotoxicidade; Bioensaio de germinação; Bio-herbicida.

\section{Resumen}

El ácido salicílico tiene una de sus características el potencial alelopático. El presente trabajo (investigación de carácter cuantitativo), tuvo como objetivo evaluar el potencial alelopático del ácido salicílico para identificar el mejor rango de concentración para otras sustancias puras. Los bioensayos se realizaron en una incubadora de DBO, buscando evaluar el crecimiento de la plántula midiendo la longitud de la radícula y el hipocótilo. Cada bioensayo se realizó durante 12 días. Las concentraciones de ácido salicílico utilizadas en los bioensayos fueron: 1000, 750, 500, 250, 125 y 62,5 ppm y control. Los datos obtenidos se sometieron a las pruebas: normalidad de Kolmogorov-Smirnov, ANOVA bidireccional con repetición y Tukey. Con base en los resultados obtenidos, se pudo observar que varias concentraciones demostraron diferencias significativas, es decir, existe una actividad alelopática en ambas especies (Euphorbia heterophylla y Bidens pilosa). Los aspectos más destacados fueron para las concentraciones de 750 y 1000 ppm para E. heterophylla y 500, 750 y 1000 ppm para B. pilosa. Sin embargo, no hubo diferencias significativas entre estos grupos de concentración. La longitud de la radícula fue la parte más afectada. Estos resultados pueden servir para identificar mejores concentraciones para otras sustancias puras, que generalmente se obtienen en pequeñas cantidades, siendo útiles en la formulación de un producto con características de bioherbicidas.

Palabras clave: Aleloquímicos; Bioherbicida; Fitotoxicidad; Crecimiento de plántulas.

\section{Introduction}

Allelopathy is the phenomenon in which an organism produces allelochemicals. They are released into the environment, directly or indirectly benefiting or harming another organism, influencing survival, development, growth and reproduction. Furthermore, they can act as growth regulators, as herbicides, as insecticides and protect against antimicrobial cultures (Cheng \& Cheng, 2015; Chung et al., 2018).

Some plants have the ability to release allelochemicals in order to eliminate possible herbivore predation and/or competition with other plants (Ooka \& Owens, 2018; Kong et al., 2019). Besides, it can increase allergic effects on plants and influence plants chlorophyll content (Ming et al., 2020). Allelopathic compounds can reduce the germination of seeds and/or affect the growth of weeds. Thus, it is possible to replace herbicides or even reduce intensive applications in crops (Gerhards \& Schappert, 2020).

Salicylic acid (SA) is produced by some plants, releasing through the rhizosphere, functioning as an allelopathic compound, having the potential to inhibit the growth of neighboring plants. Moreover, the SA can negatively influence the growth, interfere in seed germination, cell growth, respiration, and seedling establishment. Finally, they can act as a mechanism for regulating thermogenesis and disease resistance (Rizzini, 1970; Raskin, 1992; Vlot et al., 2009).

The recipient plants E. heterophylla and B. pilosa are considered feared in agriculture due to their high proliferation, 
harming the desired culture (Lorenzi, 1991; Kissmann \& Growth, 1993). The seeds of B. pilosa have thorns that stick to clothing, facilitating large-scale distribution. These seeds do not need depth to germinate, generating an unwanted high propagation (Kissmann \& Growth, 1993; Elshamy et al., 2019)

Herbicides are produced with an increasing degree of toxicity. Thus, it is necessary to reduce their use in order to improve environmental safety, decrease risks to human health and minimize the expansion of herbicide-tolerant plant biotypes (Iqbal et al., 2020). Chemical control is one of the most used methods. However, weeds are showing increasing resistance to herbicides, creating ongoing problems for farmers. Thus, there is a need to develop new products to combat these pests (Ooka \& Owens, 2018; Farooq et al., 2020).

The bio-herbicides are being used as a new and more sustainable alternative for weed management (Campos et al., 2019). To ensure food security, it is essential to promote sustainable control. Allelopathic control via bio-herbicides has become a good alternative for the elimination of pests, due to biodiversity, the reduction of various risks to the environment, and the improvement of human health (Ooka \& Owens, 2018; Farooq et al., 2020).

Based on the above, this paper, is a research quantitative in nature (Pereira et al., 2018), aimed to assess the allelopathic potential of the salicylic acid (SA) on the weeds E. heterophylla and B. pilosa. We seek to identify the best concentration range that negatively influences the development of these target plants. This range of salicylic acid concentration in this study can be used as a reference for other pure substances that are difficult to obtain and with allelopathic potential. Pure substances can be useful in the formulation of a product with characteristics of bio-herbicides.

\section{Methodology}

\section{Weed species}

The seeds of the weed species E. heterophylla and B. pilosa, were provided by the UTFPR Agronomy Department Campus Pato Branco. The seeds were submitted to the asepsis process, being deposited in a laminar flow chamber (H1) with UV lamp (254 nm), for about 15 minutes. Next, 25 seeds were placed in each Petri dish (100x15 mm), containing qualitative filter paper, with $2 \mathrm{~mL}$ of distilled water. Finally, the plates were deposited in a BOD (Biochemical Oxygen Demand) camera to start germination. With this choice, we seek less interference, as a seed in a latent state will not germinate through the substance, but through the state of the seed.

\section{Seed growth bioassay}

Weed seeds that presented radicle extension equal or greater than $2 \mathrm{~mm}$ (Junttila, 1973) were selected. In each new Petri dish (100X15 mm) 5 of these seeds were deposited and $2 \mathrm{~mL}$ of the SA solution were added.

A stock solution of 1000 ppm SA was prepared. Next, 5 dilutions were prepared: 750, 500, 250, 125, and 62.5 ppm. For the control, distilled water $(0 \mathrm{ppm})$ was used. For each of these concentrations, tests were carried out in triplicates for the two species evaluated.

The test was carried out in a BOD incubator, under controlled temperature conditions, at $30{ }^{\circ} \mathrm{C}$ in the day and $25{ }^{\circ} \mathrm{C}$ at night, with a 12-hour photoperiod, for both analyzed plants (Gonçalves et al., 2016). The tests took place over 12 days by measuring the length of radicle and hypocotyl, being performed every 3 days.

At the end of the test, it was possible to determine the following variables: percentages of normal (PN), abnormal (PA) and mortality (PM) seedlings, which were obtained using the following equations (Oliveira et al., 2010; Silva, 2014):

$$
P N=\left(\frac{n_{r}}{T}\right) \times 100
$$




$$
\begin{aligned}
& P A=\left(\frac{A}{T}\right) \times 100 \\
& P M=\left(\frac{M}{T}\right) \times 100
\end{aligned}
$$

Where: $\mathrm{n}_{\mathrm{r}}=$ number of normal seedlings; $\mathrm{A}=$ number of abnormal seedlings; $\mathrm{M}=$ number of mortality seedlings; and $\mathrm{T}=$ total number of seeds to be germinated.

\section{Statistical treatment}

The results obtained were submitted to several statistical tests with the support of the Statistica ${ }^{\circledR}$ software, with a significance level of $5 \%$ for all tests. First, the normality of the data was verified using the Kolmogorov-Smirnov test. With the confirmation of the normality of the data, two-way ANOVA (ANalysis Of VAriance) with replication tests were applied. Finally, for tests that rejected the null hypothesis, the Tukey test was applied.

\section{Results and Discussion}

\section{Statistical tests}

Initially, normality was verified via Kolmogorov-Smirnov, evaluating the p-value for variables radicle and hypocotyl length, for both species. All variables showed $\mathrm{p}<0,01$. Subsequently, two-way ANOVA was performed with repetition. From the obtained values, it was observed that the data present significant differences $p<0,05$.

Additionally, pre-tests visual were carried out to assess the existence of significant differences among groups. Through the confidence interval graphs, it has identified which concentrations proved significant differences at the level of 5\%.

For the species E. heterophylla, shown in Figure 1a, it was observed that the radicle's length decreased with the increasing salicylic acid concentration. However, between the two pairs of concentrations 125 and $250 \mathrm{ppm}$ and 750 and 1000 ppm, there were no significant differences between them. On the other hand, for the hypocotyl's length, represented in Figure $1 \mathrm{~b}$, the concentrations $0,62.5$, and $125 \mathrm{ppm}$ and 750 and $1000 \mathrm{ppm}$ did not show significant differences.

Figure 1 - Confidence intervals for the length averages for the species E. heterophylla.
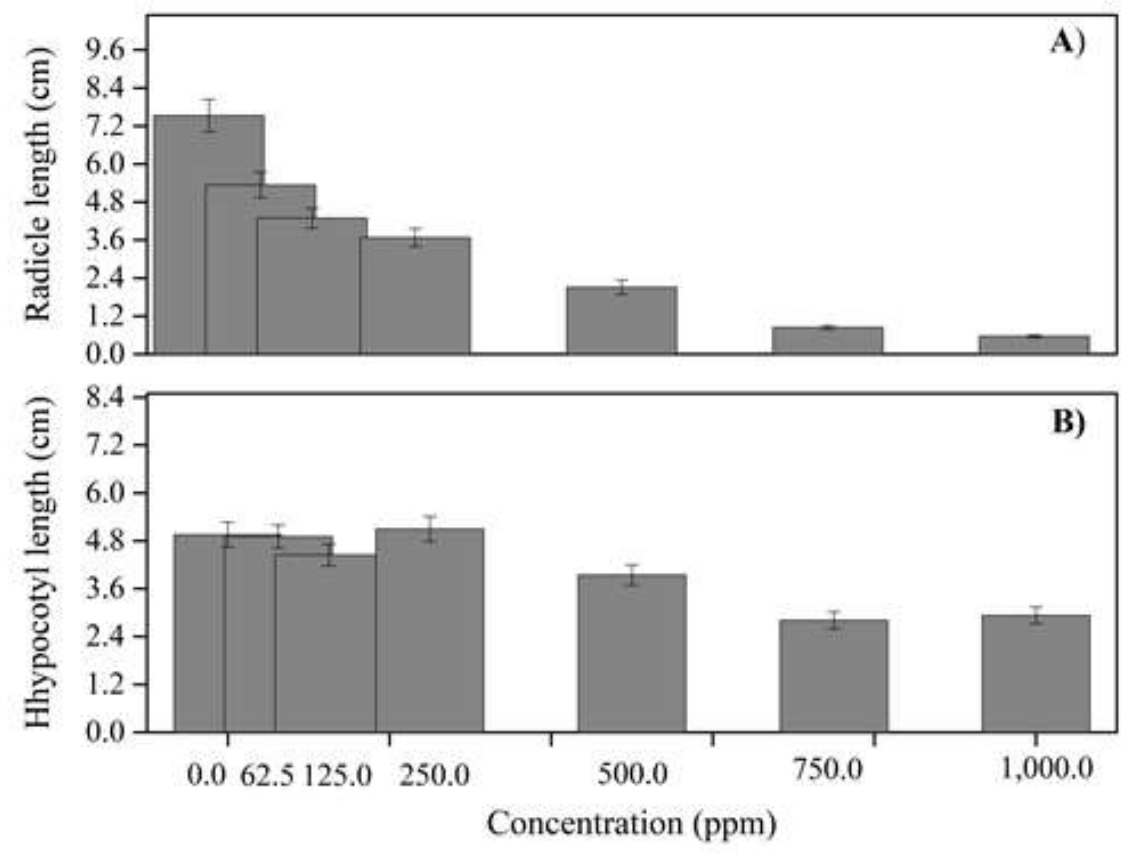

Source: Created by the authors in Statistica ${ }^{\circledR}$ software. 
For the species B. pilosa, Figure 2a, the same behavior of E. heterophylla was observed for the radicle, which showed a reduction with the increase of the SA concentration. However, the concentration 62.5 and 125 ppm and 500, 750, and 1000 ppm did not show significant differences. For the hypocotyl's length, represented in Figure $2 b$, there was no significant difference in the concentration 0 and 250 ppm; 62.5 and 125 ppm; and 750 and 1000 ppm.

Figure 2 - Confidence intervals for the length averages for the species B. pilosa.

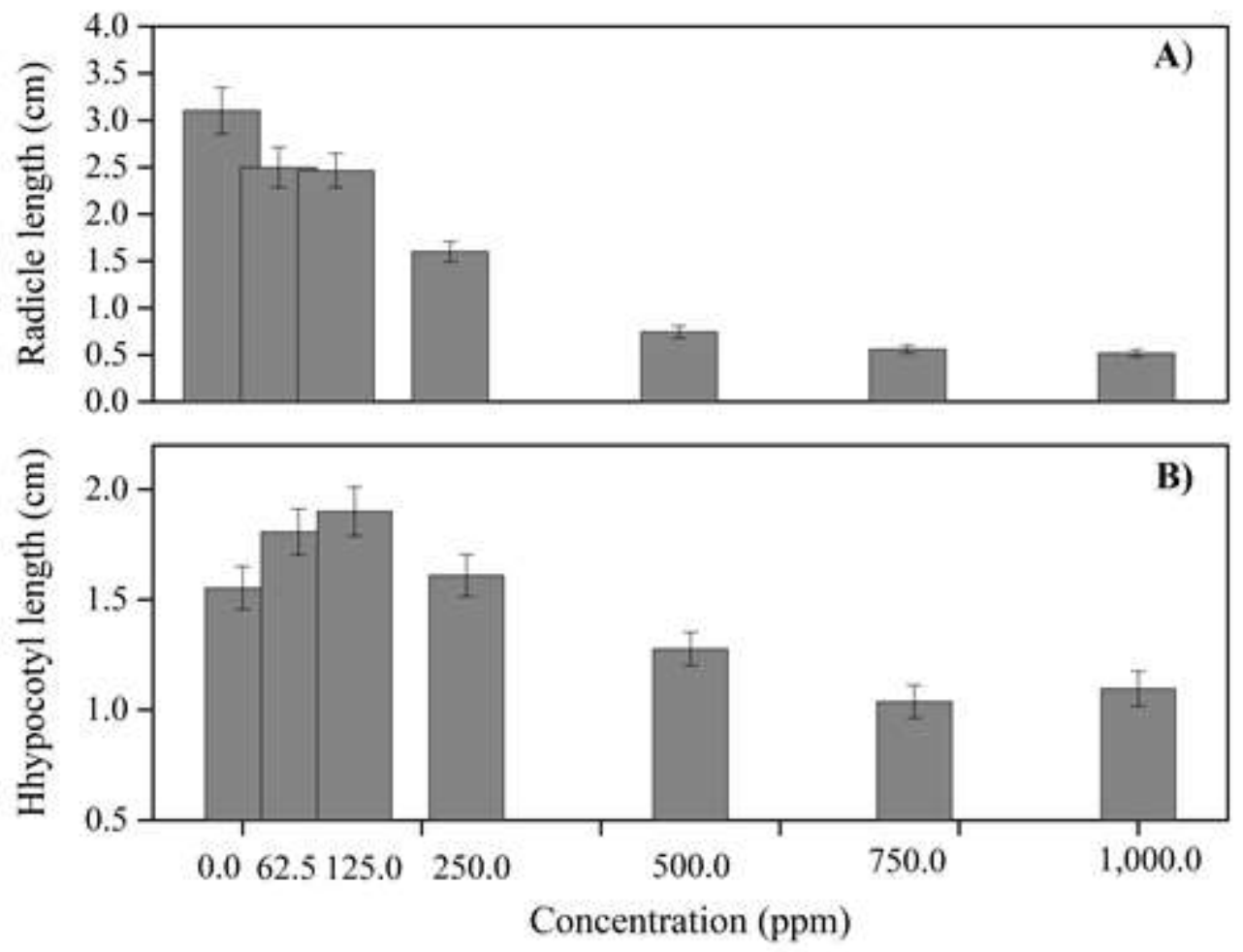

Source: Created by the authors in Statistica ${ }^{\circledR}$ software.

A possible interference factor in the hypocotyl's length (Figures $1 b$ and $2 b$ ) is the hormone effect, i.e., some toxic substances can stimulate growth and increase productivity when in small quantities. This paradoxical effect is beneficial in low doses of stress (Calabrese \& Baldwin, 2002; Ji, 2002; Pereira \& Souza Jr, 2005).

The increase in the concentration directly interfered in the radicle's length over time, illustrated in Figure 3 . The concentrations 750 and 1000 ppm were those with the lowest variation rate in the averages and a low rate of growth during the test for both species receivers. 
Figure 3 - Confidence interval of the average radicle's length as a function of the time and concentration for species: (a) $E$. heterophylla and (b) B. pilosa.
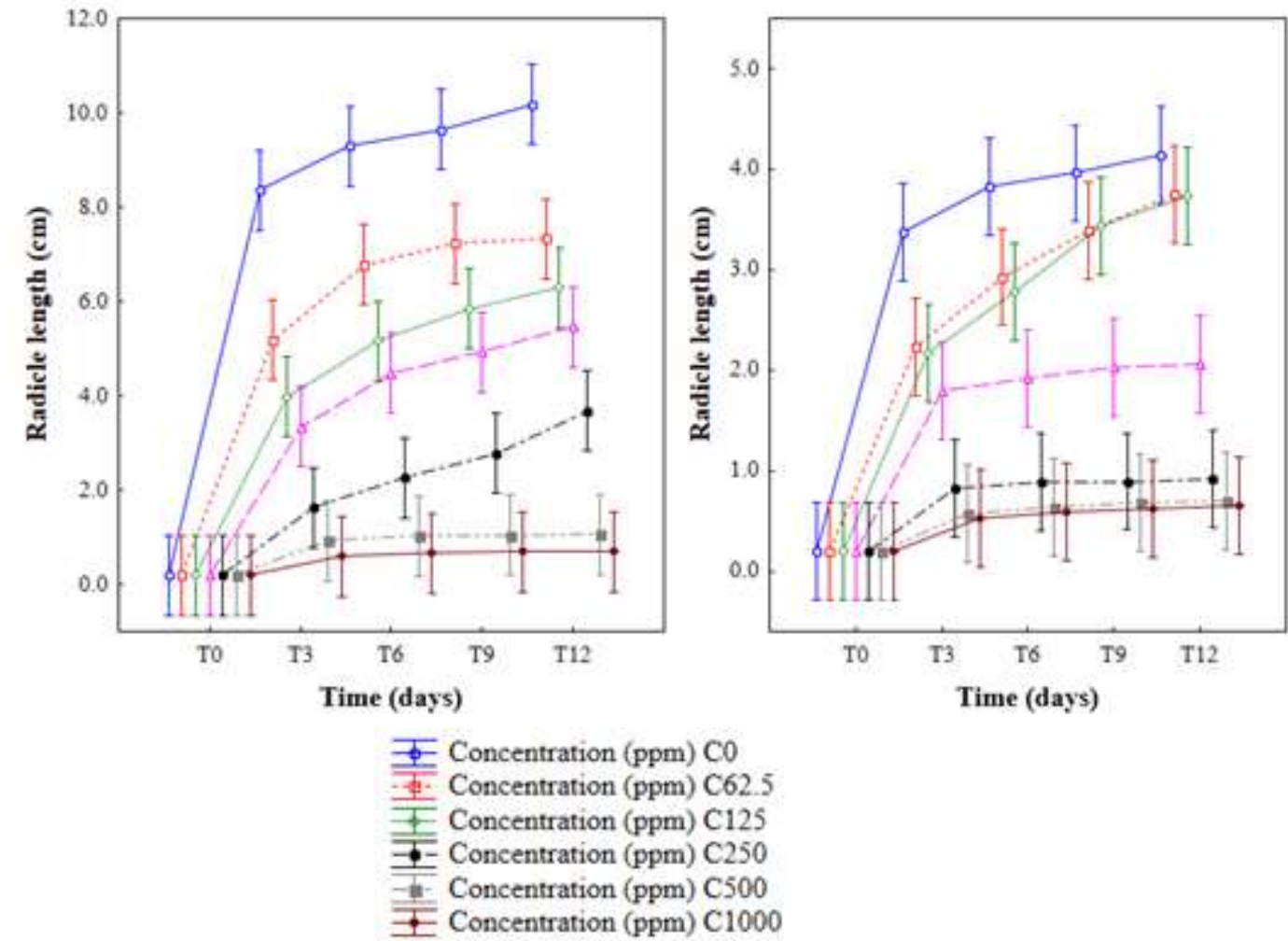

Source: Created by the authors in Statistica ${ }^{\circledR}$ software.

The radicle is the most sensitive part of the seedling to allelopathic effects. Due to contact of the root with the solution and the better absorption of allelochemicals occur. In this case, allelochemicals link to plant membranes or penetrate cells, interfering with the plant's development and growth (Souza Filho et al. 1997; Ferreira \& Aquila 2000).

The Tukey tests confirmed the results presented by the visual tests. However, both the time (days) and concentration (ppm) were assessment. The Table 1 shown the evaluation the radicle's length concerning time for the species E. heterophylla., There were no significant differences between 6 and 9 days; and 9 and 12 days, and for concentrations 125 and 250 ppm and 750 and $1000 \mathrm{ppm}$. On the other hand, for the hypocotyl's length compared to time, all showed significant differences. The concentrations $0,62.5$, and $250 \mathrm{ppm}$ and the 750 and $1000 \mathrm{ppm}$ did not show significant differences.

Table 1 - Produced Data via Tukey test for the species E. heterophylla.

\begin{tabular}{ccc}
\hline Time (days) & Radicle's length (cm) & Hypocotyl's length $(\mathbf{c m})$ \\
\hline $\mathbf{T}_{\mathbf{0}}$ & $0,20^{\mathrm{d}}$ & $0,10^{\mathrm{e}}$ \\
$\mathbf{T}_{\mathbf{3}}$ & $3,43^{\mathrm{c}}$ & $4,50^{\mathrm{d}}$ \\
$\mathbf{T}_{\mathbf{6}}$ & $4,24^{\mathrm{b}}$ & $5,01^{\mathrm{c}}$ \\
$\mathbf{T}_{\mathbf{9}}$ & $4,60^{\mathrm{ab}}$ & $5,38^{\mathrm{b}}$ \\
$\mathbf{T}_{\mathbf{1 2}}$ & $4,95^{\mathrm{a}}$ & $5,78^{\mathrm{a}}$ \\
\hline Concentration (ppm) & & \\
$\mathbf{C}_{\mathbf{0}}$ & $7,53^{\mathrm{a}}$ & $4,96^{\mathrm{a}}$ \\
$\mathbf{C}_{\mathbf{6 2}, \mathbf{5}}$ & $5,34^{\mathrm{b}}$ & $4,91^{\mathrm{a}}$ \\
$\mathbf{C}_{\mathbf{1 2 5}}$ & $4,29^{\mathrm{c}}$ & $4,45^{\mathrm{b}}$ \\
$\mathbf{C}_{\mathbf{2 5 0}}$ & $3,68^{\mathrm{c}}$ & $5,10^{\mathrm{a}}$ \\
$\mathbf{C}_{\mathbf{5 0 0}}$ & $2,11^{\mathrm{d}}$ & $3,95^{\mathrm{c}}$ \\
$\mathbf{C}_{\mathbf{7 5 0}}$ & $0,85^{\mathrm{e}}$ & $2,93^{\mathrm{d}}$ \\
$\mathbf{C}_{\mathbf{1 0 0 0}}$ & $0,56^{\mathrm{e}}$ & $2,93^{\mathrm{d}}$ \\
\hline
\end{tabular}

Source: Authors. 
For the species B. pilosa, shown in Table 2, the radicle's length compared to time, 3 and 6 days and 6, 9 and, 12 days not showed significant differences. The concentrations 62.5 and 125 ppm and 500, 750, and 1000 ppm not showed significant differences. For the hypocotyl's length, comparison to time, 6 and 9 days and 9 and 12 days, and for the concentrations 0 and 250 ppm; 62.5 and 125 ppm; and 750 and 1000 ppm not showed significant differences.

Table 2 - Produced Data via Tukey test for the species B. pilosa.

\begin{tabular}{ccc}
\hline Time (days) & Radicle's length (cm) & Hypocotyl's length (cm) \\
\hline $\mathbf{T}_{\mathbf{0}}$ & $0,20^{\mathrm{c}}$ & $0,10^{\mathrm{d}}$ \\
$\mathbf{T}_{\mathbf{3}}$ & $1,64^{\mathrm{b}}$ & $1,56^{\mathrm{c}}$ \\
$\mathbf{T}_{\mathbf{6}}$ & $1,94^{\mathrm{ab}}$ & $1,78^{\mathrm{b}}$ \\
$\mathbf{T}_{\mathbf{9}}$ & $2,14^{\mathrm{a}}$ & $1,90^{\mathrm{ab}}$ \\
$\mathbf{T}_{\mathbf{1 2}}$ & $2,28^{\mathrm{a}}$ & $2,00^{\mathrm{a}}$ \\
\hline Concentration (ppm) & & \\
\hline $\mathbf{C}_{\mathbf{0}}$ & $3,10^{\mathrm{a}}$ & $1,55^{\mathrm{b}}$ \\
$\mathbf{C}_{\mathbf{6 2}, 5}$ & $2,50^{\mathrm{b}}$ & $1,81^{\mathrm{a}}$ \\
$\mathbf{C}_{\mathbf{1 2 5}}$ & $2,46^{\mathrm{b}}$ & $1,90^{\mathrm{a}}$ \\
$\mathbf{C}_{\mathbf{2 5 0}}$ & $1,60^{\mathrm{c}}$ & $1,61^{\mathrm{b}}$ \\
$\mathbf{C}_{\mathbf{5 0 0}}$ & $0,74^{\mathrm{d}}$ & $1,28^{\mathrm{c}}$ \\
$\mathbf{C}_{\mathbf{7 5 0}}$ & $0,56^{\mathrm{d}}$ & $1,04^{\mathrm{d}}$ \\
$\mathbf{C}_{\mathbf{1 0 0 0}}$ & $0,52^{\mathrm{d}}$ & $1,10^{\mathrm{d}}$ \\
\multicolumn{3}{c}{}
\end{tabular}

Through the analysis and interpretation of these results, it is possible to determine the best concentrations to be used in future allelopathic tests with pure substances. On this context, we guide the use of concentrations that showed significant differences among them. On the other hand, we recommend using the lowest concentration that did not show significant differences. In this case, we can reduce the amount of pure substance, considering the difficulty of obtaining it. In this way, we reduced the cost of developing the test.

So far, we have evaluated the growth rate. However, the abnormalities and mortality of seedlings remain to be assessed. With this, we can evaluate the potential of SA in terms of seedling growth and mortality. For this, we will evaluate the percentages of normal (PN), abnormal (PA), and mortality (PM) seedlings.

\section{$P N, P A$ and $P D$}

On the last day of analysis (12), normal, abnormal, and mortality seedlings were counted. Abnormal seedlings are considered to have partial or total necrosis and/or some malformation.

For the species E. heterophylla, represented in Figure 4, the control (0) and 62.5 ppm do not present abnormality and mortality due to the absence or low concentration of SA. When the concentration increases, abnormalities begin to appear, even if small, usually oxidations (necrosis) in the radicle's extension. At high concentrations (750 and 1000 ppm), it was observed the emergence of mortality and abnormalities to a greater extent, i.e., necrosis in the entire radicle and, in some cases, in the hypocotyl as well. 
Figure 4 - Evaluation of PN, PA and PM in different concentrations for the species E. heterophylla.

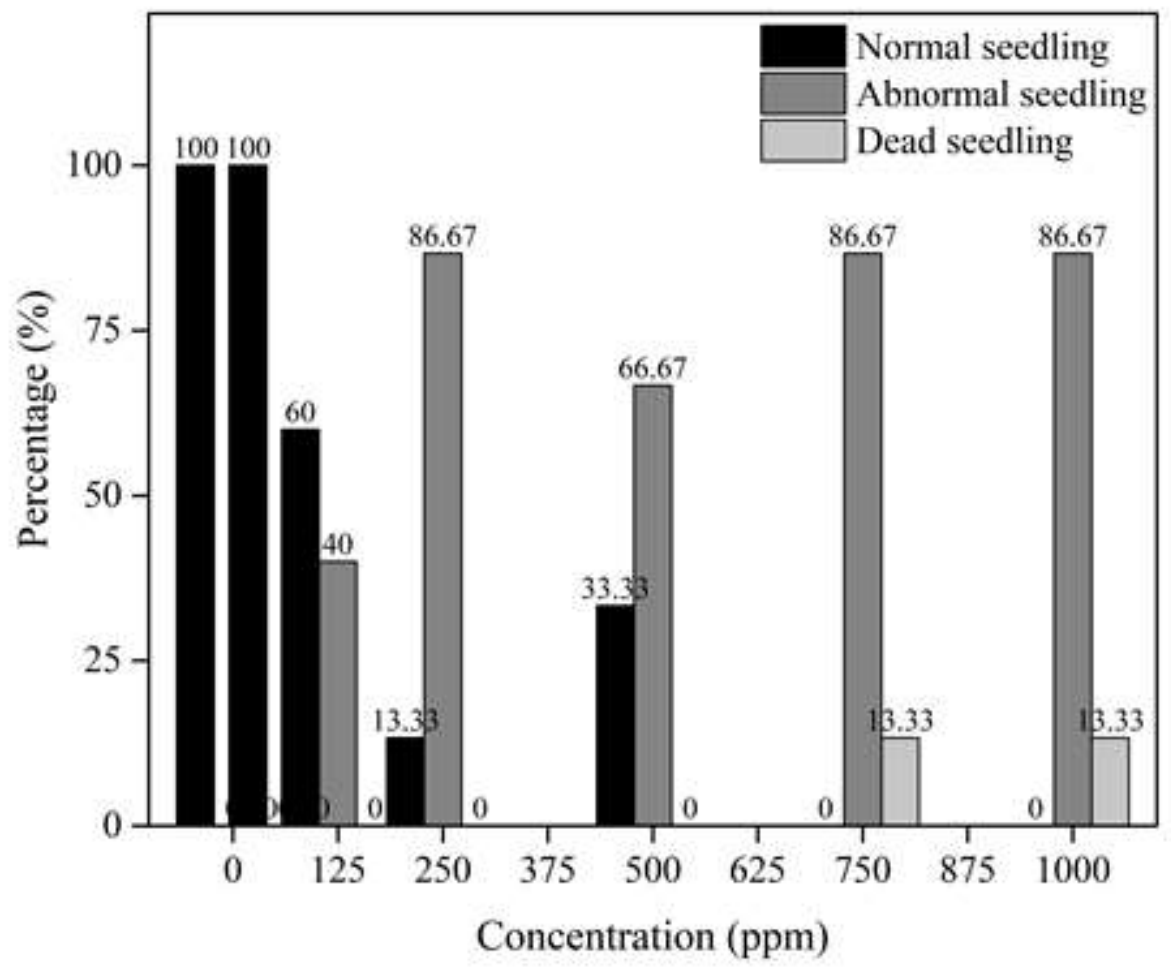

Source: Created by the authors in Statistica ${ }^{\circledR}$ software.

For the species B. pilosa, shown in Figure 5, as it is a more sensitive plant than E. heterophylla, since the concentration $62.5 \mathrm{ppm}$, the appearance of abnormalities was already observed. Mortality occurred only at concentrations above $750 \mathrm{ppm}$. These concentrations showed a higher rate of abnormality, with a greater extent of necrosis. 
Figure 5 - Evaluation of PN, PA and PM in different concentrations for the species B. pilosa.

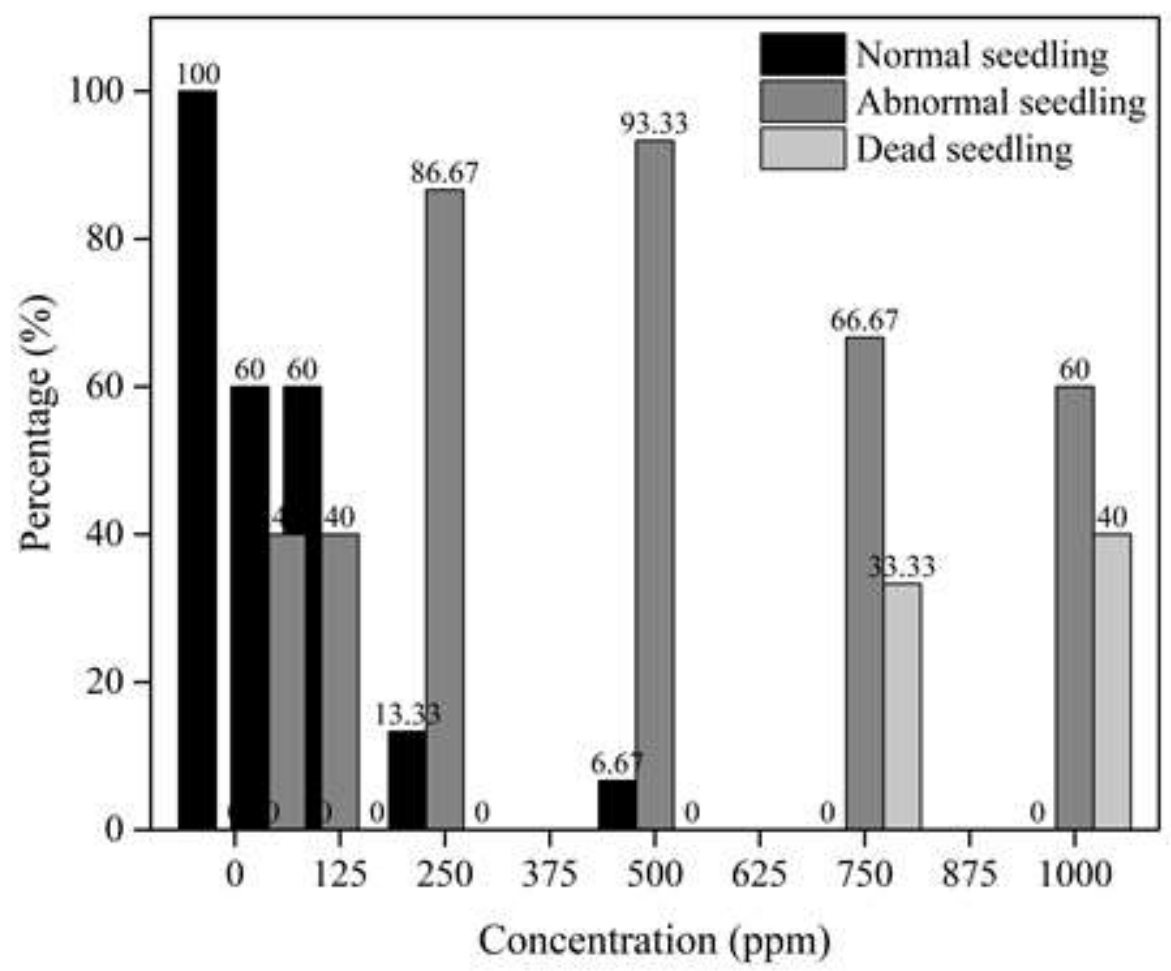

Source: Created by the authors in Statistica ${ }^{\circledR}$ software.

It was observed that the greatest damage to the seedlings was due to abnormality, presenting total or partial necrosis. In this context, concerning the total number of seeds, the observed rates were $55.24 \%$ and $52.8 \%$ for the species $B$. pilosa and E. heterophylla, respectively.

The greatest abnormalities occurred in the radicle, the site of nutrient absorption. As already discussed about nutrient absorption, any minimal damage is desirable. The radicle damage will influence nutrient absorption and seedling growth in the future (Souza Filho et al. 1997).

Any inhibition that occurs, even if small, reduces the competitiveness among plants, favoring the development of the species of interest. This favor increasing productivity, being of great importance for the economy. Furthermore, it presents favorable ecological implications due to reduced use of herbicides.

\section{Conclusion}

Salicylic acid (SA) was efficient when tested as an allelopathic compound, mainly for reducing the radicle's length, being inversely proportional to the concentration. Another relevant result was related to abnormalities and mortality, mainly in the concentrations 750 and 1000 ppm, being important factors for reducing or eliminating weeds. The species $B$. pilos $a$ was the most influenced, in terms of abnormalities and mortality, due to its greater sensitivity, when compared to E. heterophylla. The results were promising, since they showed significant differences between them, mainly in the radicle's length. Based on these results, it is possible to determine an efficient concentration range. That results can be used in similar bioassays with other pure substances with characteristic allelopathic. When choosing concentrations that did not differ significantly from each other, we 
recommend using the lowest concentration in order to reduce costs. In the future, we will carry out bioassays with pure substances of interest, with the same target plants, enabling the formulation of a product with characteristics of bio-herbicides.

It is important to emphasize that, from the results of this work, new research can be developed in order to know the different possibilities that pure substances, secondary metabolites obtained from living organisms and/or their analogues, with allelopathic potential can provide, both as products for the biocontrol of harmful species, such as providing model molecules for the synthesis of bio-herbicides, or even facilitating the understanding of the mechanism of action of these bioactive metabolites.

\section{Acknowledgments}

This work was supported by the Federal University of Technology - Paraná (UTFPR) - Campus Pato Branco by financial support in the execution of undergraduate final project works and by CAPES for the master's scholarship.

\section{References}

Calabrese E. J. \& Baldwin L. A. (2002). Applications of hormesis in toxicology, risk assessment and chemotherapeutics. Trends in Pharmacological Sciences 23, 331-337. 10.1016/s0165-6147 (02) 02034-5.

Campos J. A., Peco J. D. \& García-Noguero E. (2019). Antigerminative comparison between naturally occurring naphthoquinones and commercial pesticides. Soil dehydrogenase activity used as bioindicator to test soil toxicity. Science of the Total Environment, 694, 133672. 10.1016/j.scitotenv.2019.133672.

Cheng F. \& Cheng Z. (2015). Research progress on the use of plant allelopathy in agriculture and the physiological and ecological mechanisms of allelopathy. Frontiers in Plant Science, 6, 1020. 10.3389/fpls.2015.01020.

Chung I. M., Park S. K., Thiruvengadam M., Lee J. H., Kim S. H. \& Rajakumar G. (2018). Review of the biotechnological applications of rice allelopathy in agricultural production. Weed Biology and Management, 18, 63-74. 10.1111/wbm.12145.

Elshamy A. I., Abd-Elgawad A. M., El Gendy Aeng \& Assaeed A. M. (2019). Chemical Characterization of Euphorbia heterophylla L. Essential Oils and Their Antioxidant Activity and Allelopathic Potential on Cenchrus echinatus L. Chemistry \& Biodiversity, 16 (5). 10.1002/cbdv.201900051

Farooq N., Abbas T., Tanveer A. \& Jabran K. (2020). Allelopathy for Weed Management. In Mérillon J. M. \& Ramawat K. G. (Eds), Co-Evolution of Secondary Metabolites. Springer International Publishing, p. 505-519.

Ferreira A. G. \& Aquila M. E. A. (2000). Alelopatia: uma área emergente da Ecofisiologia. Revista Brasileira de Fisiologia Vegetal, $12,175-204$.

Gerhards R. \& Schappert A. (2020). Advancing cover cropping in temperate integrated weed management. Pest Management Science, 76, 42-46. $10.1002 /$ ps.5639.

Gonçalves V. D., Coelho M. F. B, Camili E. C. \& Valentini C. M. A. (2016). Allelopathic potential of Inga laurina leaf extract on lettuce seed germination. Científica, 44, 333-337. 10.15361/1984-5529.2016v44n3p333-337.

Iqbal N., Khaliq A. \& Cheema Z. A. (2020). Weed control through allelopathic crop water extracts and S-metolachlor in cotton. Information Processing in Agriculture, 7, 165-172. 10.1016/j.inpa.2019.03.006.

Ji L. L. (2002). Exercise-induced modulation of antioxidant defense. Annals of the New York Academy of Sciences, 959, 82-92. 10.1111/j.17496632.2002.tb02085.x.

Junttila O. (1973). Seed and embryo germination in S. vulgaris and S. reflexa as affected by temperature during seed development. Physiologia Plantarum, 29, 264-268. 10.1111/j.1399-3054.1973.tb03103.x.

Kissmann K. G. \& Groth D. (1933). Plantas Infestante e nocivas. BASF.

Kong C. H., Xuan T. D., Khanh T. D., Tran H. D. \& Trung N. T. (2019). Allelochemicals and Signaling Chemicals in Plants. Molecules (Basel, Switzerland), 24, 2737. 10.3390 / moléculas24152737.

Lorenzi H. (1991). Plantas daninhas do Brasil: terrestres, aquáticas, parasitas e tóxicas, (4a ed.) Plantarum. 640 p.

Ming Y., Zhu Z., Li J., Hu G., Fan X. \& Yuan D. (2020). Allelopathic Effects of Castanea henryi Aqueous Extracts on the Growth and Physiology of Brassica pekinensis and Zea mays. Chemistry \& Biodiversity, 17. 10.1002 / cbdv.202000135

Oliveira M. C., Ferreira G., Guimarães V. F. \& Dias G. B. (2010). Germinação de sementes de atemoia (Annona cherimola mill. × A. squamosa L.) CV 'Gefner' submetidas a tratamentos com ácido giberélico (GA3) e ethephon. Revista Brasileira de Fruticultura, 32, 544-554. 10.1590/S010029452010005000062.

Ooka J. K. \& Owens D. K. (2018) Allelopathy in tropical and subtropical species. Phytochemistry Reviews, 17, 1225-1237. 10.1007/s11101-018-9596-7. 
Research, Society and Development, v. 11, n. 1, e6911124863, 2022

(CC BY 4.0) | ISSN 2525-3409 | DOI: http://dx.doi.org/10.33448/rsd-v11i1.24863

Pereira B. \& Souza Jr. T.P. (2005). Adaptação e rendimento físico - considerações biológicas e antropológicas. Revista Brasileira de Ciência e Movimento, $13,145-152$.

Pereira A. S., Shitsuka D. M., Parreira. F. J. \& Shitsuka R. (2018). Metodologia da pesquisa científica. UFSM

Raskin I. (1992). Role of Salicylic Acid in Plants. Annual Review of Plant Physiology and Plant Molecular Biology, 43, 439-463.

Rizzini C. T. (1970). Inibidores de germinação e crescimento em Andira humilis Benth. Anais da Academia Brasileira de Ciências, 329-366.

Silva M. G. F. (2014). Avaliação do potencial alelopático de raízes de capim annoni-2 (Eragrostis plana Nees) e estudo fitoquímico. Universidade Tecnológica Federal do Paraná,

Souza Filho A. P. S, Rodrigues L. R. A \& Rodrigues T. J. D. (1997). Efeitos do potencial alelopático de três leguminosas forrageiras sobre três invasoras de pastagens. Pesquisa Agropecuária Brasileira, 32, 165-170.

Vlot A. C., Dempsey D. A. \& Klessig D. F. (2009). Salicylic Acid, a Multifaceted Hormone to Combat Disease. Annual Review of Phytopathology, 47, 177206. 10.1146/annurev.phyto.050908.135202. 